\title{
Aggregations and temporal changes in the activity and bioturbation contribution of the sea cucumber Holothuria whitmaei (Echinodermata: Holothuroidea)
}

\author{
Glenn R. Shiell ${ }^{1, *}$, Brenton Knott \\ ${ }^{1}$ Animal Biology (MO92), The University of Western Australia, 35 Stirling Highway, Crawley, Perth, WA 6009, Australia \\ ${ }^{2}$ Present address: Oceanica Consulting Pty. Ltd., PO Box 3172, Broadway, Nedlands, Perth, WA 6009, Australia
}

\begin{abstract}
The population density, activity and bioturbation contribution of the sea cucumber Holothuria whitmaei was investigated on Ningaloo Reef, Western Australia. Two methods, stratified manta tows and blanket manta tows, recorded population densities between 11.4 and >100 individuals (ind.) ha ${ }^{-1}$. Further analysis revealed a heterogeneous pattern of distribution, with individuals tending to aggregate (Moran's I; 0.039; $\mathrm{p}<0.05$ ) on the outer reef lagoon and particularly in areas of high flow. Densities within aggregations were up to 7.2 times greater than those obtained after blanket manta tows (17.1 ind. ha ${ }^{-1}$ ), and 4.5 to 6.3 times greater than those obtained after traditional stratified manta tows (19.3 to 27.1 ind. ha ${ }^{-1}$ ). Behavioural studies, including investigations of activity and bioturbation, were conducted over a 2 yr time frame (2002-2003) incorporating 3 monitoring periods within each year: January, April and August. Rates of activity varied diurnally, increasing between morning and afternoon, and seasonally, increasing in April, relative to January and August. Temporal patterns of feeding were more difficult to characterise; although rates of sediment egestion were in many cases higher in the morning, no conclusive diurnal or seasonal patterns could be established. Subsequent regression analysis, however, did find a significant positive correlation between the distance travelled and the volume of sediment egested. The volume of sediment bioturbated by $H$. whitmaei at a population level was found to represent only a small fraction of the sediments available (ca. 2 to $14 \%$ per annum), even though the contribution per individual was greater than that of smaller sea cucumber species. However, at maximum densities and typical rates of activity, H. whitmeai makes physical contact with approximately 2 times the available coral reef sediments per annum per hectare, simply by crawling. This may represent an important ecological contribution, particularly in light of previously documented links between sea cucumber activity, nutrient recycling and the enhancement of benthic microalgal communities.
\end{abstract}

KEY WORDS: Aggregation - Behavioural activity - Bioturbation · Coral reef lagoon · Densitydependent effects

Resale or republication not permitted without written consent of the publisher

\section{INTRODUCTION}

The Pacific and Indian Ocean black teatfish Holothuria (Microthele) whitmaei (previously H. nobilis; see Uthicke et al. 2004) is one of $\sim 30$ species of sea cucumbers (Conand 2004) harvested for commercial purposes (Chen 2004, Uthicke et al. 2004). Increasing demand for sea cucumbers has led to a significant increase in commercial and illegal exploitation of wild sea cucumbers (Toral-Granda et al. 2008), particularly for high-value species such as $H$. whitmaei and $H$. scabra (Uthicke \& Benzie 2000a, Rees et al. 2003). As many high-value species maintain naturally low population densities, fishers maintain commercial viability by simultaneously targeting a range of high-, mediumand low-value species. Traditionally, this has con- 
tributed to a 'boom and bust' cycle where high-value sea cucumbers are targeted preferentially, leading to high-value species being fished to near local extinction (Rees et al. 2003) or to levels too low to sustain the fishery (Uthicke \& Benzie 2000a).

Previous studies of the ecology and biology of Holothuria whitmaei centred on the Great Barrier Reef (GBR), Queensland, Australia (Uthicke \& Karez 1999, Uthicke \& Benzie 2000a,b, 2002, 2003, Byrne et al. 2004, Uthicke et al. 2004) and elsewhere in the broader Pacific Ocean (Conand 1981, 1993, Martinez \& Richmond 1998). Several of these provide useful descriptions of the habitat preferences of $H$. whitmaei, which are described broadly as the reef flat, the reef lagoon, the mid and outer reef shelf and passes, or 'gaps', in the crest of barrier and fringing coral reefs (Conand 1985, 1990, 1993, Hammond et al. 1985, Massin \& Doumen 1986, Preston 1993, Long et al. 1996, Uthicke \& Benzie 2000a). Densities of $H$. whitmaei within these habitats are typically low, ranging between 5 and 25 individuals (ind.) $\mathrm{ha}^{-1}$ (Massin \& Doumen 1986, Conand 1989, 1990, Preston 1993, Long et al. 1996, Lawrence et al. 2004); however, densities of 100 to 275 ind. ha ${ }^{-1}$ have been reported (Conand 1989, Lokani 1990, Byrne et al. 2004, Kinch et al. 2008).

Activity behaviour in sea cucumbers has been linked with feeding (Hammond 1982, Massin 1982a, Shiell \& Knott 2008). Feeding in aspidochirotes is achieved by ingesting and stripping sediments of associated organic nutrients (Massin 1982a). Consequently, holothurians are strong bioturbators of the upper $5 \mathrm{~mm}$ of marine sediments (Bakus 1973, Massin 1982a,b, Aller \& Yingst 1985, Amon \& Herndl 1991). Estimates of the total bioturbation contribution of sea cucumbers vary but, at greater densities, holothurians are reported to process several tonnes of sediment per annum (Hammond 1982, Uthicke 1999). Apart from the physical manipulation of sediments, sea cucumbers, through their ingestion and metabolism of organic matter, contribute nitrogen-based compounds directly to the sediment/water interface (Massin 1982b, Birkeland 1988, Uthicke 1999, 2001a,b), thereby enhancing benthic community productivity (Uthicke \& Klumpp 1998).

Studies of the bioturbation and nutrient recycling contribution of aspidochirotes have traditionally focused on low- to medium-value holothurians (Hammond 1982, Klinger et al. 1994, Uthicke 1999, 2001a,b, Ferdouse 2004). Two of the most abundant low-value aspidochirotes of the Indo-Pacific, Holothuria atra and Stichopus chloronotus, are prolific bioturbators of coral reef sediments, processing the upper $5 \mathrm{~mm}$ of marine sediments in their habitat at least once per annum (Uthicke 1999). Similarly, a period of $\sim 1 \mathrm{yr}$ is required for Isostichopus badionotus and $H$. mexicana to rework marine sediments to a depth of $3 \mathrm{~mm}$ in the Caribbean
(Hammond 1982). In contrast, little is known of the bioturbation and ecological contribution of high-value species (but see Wiedemeyer 1992 and Wolkenhauer et al. 2010 for studies of bioturbation in the high-value sand-dwelling species $H$. scabra).

Here we investigated the population density of a high-value species Holothuria whitmaei on a 750 ha area of fringing coral reef at Ningaloo, Western Australia, using both stratified and blanket manta tow census methods. Estimates provided here are likely to represent 'natural' population densities since, to our knowledge, Ningaloo has never been subjected to commercial fishing, nor is it likely to have been affected by poaching given its distance from traditional fishing nations.

Also, we provide the first documentation of diurnal and seasonal changes in the rate of activity and bioturbation of Holothuria whitmaei and evaluate the ecological contribution of this species in the context of observed population densities. The present study, along with those of other commercially significant sea cucumbers, are urgently required given the preferential harvesting of high-value sea cucumbers and the relative lack of knowledge of sea cucumbers in comparison with other commercially important marine resources.

\section{MATERIALS AND METHODS}

Study location. Population densities and temporal changes in the foraging behaviour of Holothuria whitmaei were recorded near Coral Bay, Ningaloo Reef, Western Australia. Density surveys were conducted between Point Maud and Lotty's Lagoon (Fig. 1). Behavioural monitoring was undertaken on a 1 ha section of reef located ca. $3 \mathrm{~km}$ south of Coral Bay (see also Shiell \& Knott 2008).

Density, distribution and aggregations. Densities of Holothuria whitmaei were calculated based on the number of individuals observed after (1) stratified manta tow surveys, designed to target specific habitats; and (2) 'blanket' manta tow surveys (in conjunction with GIS analysis), designed to include all habitats. Stratified manta tow surveys ( $\mathrm{n}=9$ to 10 per location) were conducted between September 2001 and January 2002 on the outer reef lagoon at (1) Lotty's Lagoon, (2) Glass Bottom Boats (GBB) and (3) Point Maud (Fig. 1). These areas were selected based on the known habitat preferences of $H$. whitmaei described by Conand $(1985,1990,1993)$ and Uthicke \& Benzie (2000a). Transect length varied between 150 and $310 \mathrm{~m}$; transect width was $3 \mathrm{~m}$ (1.5 m either side of transect). Density estimates (ind. $\mathrm{m}^{-2}$ ) were calculated as number of individuals divided by the transect area 

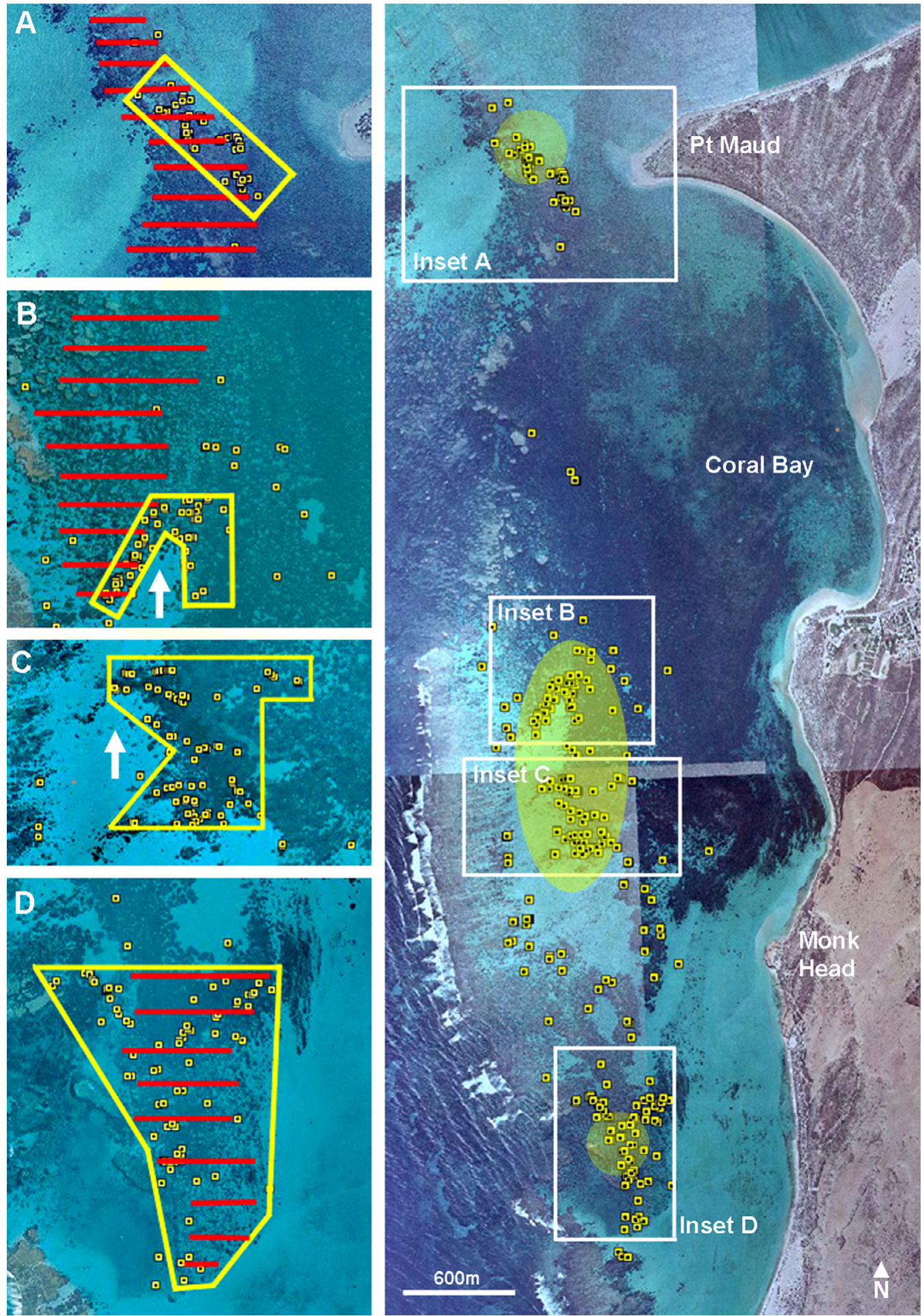

Fig. 1. Holothuria whitmaei. Aerial images of the survey region overlain with GPS waypoints (small yellow squares with black centres) representing the positions of individuals. Inset panels A, B, C and D represent, respectively, enlarged views of the Point Maud, Glass Bottom Boat, southern Glass Bottom Boat and Lotty's Lagoon sites, where individuals were significantly aggregated. Yellow shaded ellipses in the main panel represent habitats containing $40 \%$ of the sampled population following the kernel home range analysis (ArcView ${ }^{\mathrm{TM}}$, ESRI). Red horizontal bars (insets A, B \& D) represent the position of initial manta tow transects; the yellow polygons in panels A, B, C and D depict the individual areas used to calculate densities in zones containing aggregations. Arrows (insets B \& C) depict the direction of prevailing water movement (described by Hearn et al. 1986) 
(transect length $[\mathrm{m}] \times$ transect width $[\mathrm{m}]$ ). 'Blanket' manta tow surveys were (1) conducted over the entire fringing reef lagoon (including the habitats previously surveyed by stratified manta tows) and (2) modified so that the position of individual specimens could be recorded as a single GPS waypoint. To achieve this, an observer seated at the back of the boat used a handheld GPS unit to enter the position of individual sea cucumbers when the appropriate signal was given by the 'in-water' observer. The error generated by the distance between the GPS operator and the observer was considered negligible given the scale of the area (750 ha) included in the surveys.

Surveys conducted between August 2002 and April 2003 covered $\sim 750$ ha of coral reef habitat. The habitats surveyed were the reef lagoon, the reef flat, reef passes and, where possible, the reef crest. Depths ranged between 1 and $2 \mathrm{~m}$ on the reef flat, 3 and $10 \mathrm{~m}$ in the reef lagoon and up to $15 \mathrm{~m}$ adjacent to passes. Some areas of the reef, including deeper habitats adjacent to Point Maud and the area west of the reef crest, were not included in the surveys as the depths at these locations precluded effective viewing of sea cucumbers. Parallel, east-west transects (30 to $50 \mathrm{~m}$ apart) were conducted as follows: between Lotty's Lagoon and Monks Head in August 2002; between Monks Head and Coral Bay, and between Coral Bay and Point Maud in January and April 2003, respectively.

To determine the pattern of sea cucumber distribution, individual waypoints were plotted on a digitally rectified aerial photograph. Kernel home range analysis (Hooge \& Eichenlaub 1997), a GIS application within ArcView ${ }^{\mathrm{TM}}$ (ESRI), was used to identify habitats containing 'aggregations'. Aggregations were defined subjectively as areas containing $\sim 40 \%$ of the population, within disproportionately small ( 15 to $20 \%)$ areas of habitat. The $40 \%$ criterion was selected following review of different 'cut off' criteria (within the kernel analysis) together with knowledge of where the aggregations were centered, e.g. GBB, Point Maud. The extent to which areas harbouring aggregations contained significantly higher concentrations of individuals (relative to adjoining areas) was calculated using Moran's I test (Moran 1950, Cliff \&Ord 1981).

Densities were then estimated by means of GIS over 2 habitat scales: (1) within habitats containing aggregations and (2) over the full range of the habitats occupied. Part 1 of the analysis calculated 'upper' and 'lower' densities to account for the fact that the number of blanket manta tows varied between 2 and 3 per hectare. Densities within aggregations were estimated by plotting a boundary around the habitats shown by the kernel analysis to contain aggregations, and then counting the number of sea cucumbers located within (see Fig. 1 for location and extent of boundaries). In
Part 2 of the analysis, the population density incorporating the full range of distribution was calculated by plotting a boundary around the most outwardly distributed individuals. Density calculations included only the habitats known to be favoured by Holothuria whitmaei, i.e. areas containing appropriate shelter in the form of live coral or coral rubble. Areas containing large expanses of open sand or sand characterised by 'ripple marks' were not included in the estimate.

Rates of activity and sediment egestion. Diurnal rates of activity and sediment egestion (a proxy for bioturbation) were measured on 9 and 8 field trips, respectively, between January 2002 and September 2003. Eighteen individuals were included in the initial 2 field trips and 30 in subsequent field trips. Before the beginning of monitoring, adult specimens were collected by SCUBA and transferred to preselected sites within the study area (see Shiell \& Knott 2008).

Individual Holothuria whitmaei specimens were then marked with a number and left to recover for a minimum of $5 \mathrm{~d}$ following Shiell (2006). Marker plates were placed directly posterior to each animal, from which point all subsequent movement was determined (following Mercier et al. 2000, Uthicke 2001a). Upon locating a sea cucumber, divers used a plastic measuring tape to record the distance between the marker weight and the posterior end of the sea cucumber. This was achieved by bending the tape along the visible faecal trail to record the total distance travelled, not the straight line distance. The egested faecal material was then carefully collected and transferred to plastic vials for later dry weight analysis. Marker plates were then returned to the substrate immediately posterior to the sea cucumber, taking care not to disturb the animal.

Diurnal rates of activity and sediment egestion were measured in 2002 and 2003. In both years, behavioural measures were conducted in January, April and August. These months coincide with the species' reproductive phases: developing, mature and partly spawned or spent (sensu Shiell \& Uthicke 2006). On each sampling occasion, sediment egestion and activity studies proceeded over a $5 \mathrm{~d}$ period, with each day comprising 4 diurnal increments: early morning (EM), midday (MD), late afternoon (LA) and night (N). To account for differences in day length between seasons, divers commenced EM monitoring at $\sim 2 \mathrm{~h}$ after sunrise, $\mathrm{MD}$ at $\sim 4 \mathrm{~h}$ after sunrise and LA at $\sim 2 \mathrm{~h}$ before sunset. Night time rates of activity were calculated based on the number of hours between the end of the LA monitoring and the beginning of EM monitoring, a period typically spanning 12 to $14 \mathrm{~h}$. Rates of activity and sediment egestion were respectively calculated by dividing the total distance travelled $(\mathrm{cm})$ and the dry weight volume of faeces egested $(\mathrm{g})$ by the number hours $(\mathrm{h})$ between monitoring periods. 
Gut retention time. To estimate the length of time between ingestion and egestion of sediment (gut retention time), sediments from the study site were collected, dried and then stained with Alizarin Red. The organic content of stained sediments was enriched with aquaculture feed and placed in the sun for $5 \mathrm{~d}$ to encourage algal growth. The coloured sediments were then returned to the study site and transferred to the zone immediately in front of Holothuria whitmaei specimens using a 21 plastic bottle, modified to deliver controlled portions of sediment. Indicator sediments were offered to each specimen typically between 17:00 and 18:00 h. The length of time between initial application (as distinct from ingestion) of the indicator sediment and the emergence of 'red coloured' faecal material was subsequently determined.

Bioturbation. The mean dry weights (g) of faecal material collected in each of the study periods were pooled and averaged to obtain an overall rate $\left(\mathrm{g} \mathrm{d}^{-1}\right)$ of bioturbated sediment. The resulting value was subsequently multiplied by 365 to estimate the volume produced per individual per year ( $\mathrm{g}$ ind..$^{-1} \mathrm{yr}^{-1}$ ). Extrapolative calculations were then conducted to conservatively estimate the volume of sediment processed annually and the volume of sediment processed at different population densities.

To estimate the extent of bioturbation by Holothuria whitmaei, the mean volume of sediment egested over a $24 \mathrm{~h}$ period was divided by the weight of sediment contained within a $1 \mathrm{~cm} \times 1 \mathrm{~cm} \times 0.5 \mathrm{~mm}$ cube (equivalent to the approximate depth of sediment ingested by holothurians). The resulting average weight of the sediment $(\mathrm{n}=30)$ was subsequently scaled up to represent the total surface area covered by an individual over the course of a single year (ind. $\mathrm{yr}^{-1}$ ) and the total surface area covered over the same time period at different population densities. The resulting sediment volumes were subsequently multiplied by 0.5 to account for the notion that approximately $50 \%$ of the coral reef habitat consists of sand; remaining habitats typically comprise hard, non-bioturbatable substrates, including live coral and coral rubble (as described by Rasheed et al. 2002).

To complement the data on the volume of sediment bioturbated, the total surface area of sediment in contact with the ventral foot of Holothuria whitmaei was also determined. This was calculated by multiplying the average daily rate of activity $\left(\mathrm{cm} \mathrm{d}^{-1}\right)$ by the average breadth of the sea cucumber's ventral surface (11.92 cm, based on $\mathrm{n}=30$ haphazard measurements) (following Uthicke 2001a).

Statistical analyses. Global Moran's I (Moran 1950, Cliff \& Ord 1981) test was used to determine whether the pattern of sea cucumber distribution was aggregated, dispersed or random. The test is based on a randomization null hypothesis computation. Upon detection of a statistically significant result $(\alpha=0.05)$, a positive Moran's I index value indicates tendency toward clustering (aggregation), while a negative Moran's I index value indicates tendency toward dispersion.

To determine differences in patterns of activity and egestion between months, statistical analyses were conducted with data from each of the 4 diurnal monitoring increments, namely, EM, MD, LA and N. All observations in the months January 2002, April 2002 and August 2003 used a different set of individuals, and hence each of the observations were independent. However, in situations where 2 studies were conducted in the same month of the same year (i.e. in August 2002, January 2003 and April 2003) rates of activity and sediment egestion data for each of the animals were paired and averaged. This was necessary to (1) achieve a symmetrical design (i.e. month [fixed factor with 3 levels] and year [random factor with 2 levels]) and (2) ensure that each of the months contained independent observations, both desirable prerequisites for ANOVA procedures. For this analysis, month was considered to be a fixed factor to account for the fact that January, April and August represented fixed phases of the reproductive cycle (Shiell \& Uthicke 2006).

Rates of activity $\left(\mathrm{cm} \mathrm{h}^{-1}\right)$ and sediment egestion $\left(\mathrm{g} \mathrm{h}^{-1}\right)$ obtained over the $5 \mathrm{~d}$ study period for each of the animals ( $\mathrm{n}=18$ to 30 ) were averaged and $\sqrt{x+0.5}$ transformed (Fowler et al. 1998). The effect of time of day $(\mathrm{T})$, month $(\mathrm{M})$ and year $(\mathrm{Y})$ on rates of activity and sediment egestion was subsequently assessed with separate 3-way ANOVA procedures. In both examples, $\mathrm{T}$ was treated as a repeated measures variable with 4 levels (EM, MD, LA and N), M as a fixed factor with 3 levels (January, April and August) and Y as a random factor with 2 levels (2002 and 2003). An additional ANOVA was performed to determine the effect of $\mathrm{M}$ and $\mathrm{Y}$ on $\sqrt{\mathrm{X}+0.5}$ transformed LA rates of activity. For this ANOVA, $\mathrm{M}$ and $\mathrm{Y}$ were treated as fixed and random factors, respectively. LA rates of activity were analysed separately given that the difference between months was most pronounced at this time.

\section{RESULTS}

\section{Density, distribution and aggregations}

When plotted on the aerial photograph, the distribution of Holothuria whitmaei suggests a preference for habitats situated in the outer reef lagoon, and particularly at the edge of the reef lagoon adjacent to large expanses of sand (Fig. 1). The apparent preference for 
habitats at the edge of the reef lagoon was most pronounced at GBB and southern Glass Bottom Boat (SGBB), where individuals tended to aggregate in large numbers (Fig. 1, insets B \& C). Relatively large numbers of $H$. whitmaei were observed on the outer reef lagoon to the east of Lotty's Lagoon (Fig. 1, inset D), and adjacent to Point Maud (Fig. 1, inset A). Several specimens were also surveyed within the midreef lagoon (<6 m depth), where individuals were observed intermittently on patches of sand among coral heads. No individuals were observed within $500 \mathrm{~m}$ of the shoreline, nor were they observed upon large expanses of open sand, or sand characterised by 'ripple marks'.

Significant aggregations $(\mathrm{n}=124$, Moran's I = 0.039, normality $Z=2.973, \mathrm{p}=0.01$ ) were observed at 3 locations: the outer reef lagoon at Lotty's Lagoon, Point Maud and at GBB/SGBB (Fig. 1). Aggregations are depicted in Fig. 1 as yellow-shaded ellipses. Aggregations at GBB/SGBB occurred particularly on the leading edge of the outer reef lagoon (Fig. 1, insets B \& C) (Hearn et al. 1986, Sanderson 1996). These habitats lie perpendicular to prevailing water currents, which typically move in a northerly direction. Aggregations at Point Maud and Lotty's Lagoon, although not obviously centred upon the leading edges of the reef lagoon, were positioned in areas characterised by strong water movement (G. Shiell pers. obs.).

Density estimates based on stratified manta tow surveys were relatively consistent but lacked precision. Densities $( \pm 1$ SD) were estimated at $19.3( \pm 20), 27.1$ $( \pm 17)$ and $25.9( \pm 35)$ ind. ha $^{-1}$ at Lotty's Lagoon, GBB and Point Maud, respectively. These estimates contrasted with those obtained after blanket manta tows, particularly in aggregations. Within aggregations, lower and upper densities were estimated at 30.0 to 45.1 ind. ha ${ }^{-1}$ and 69.6 to 104.4 ind. ha ${ }^{-1}$ at Lotty's Lagoon and GBB, respectively, and 52.3 to 78.5 ind. $\mathrm{ha}^{-1}$ and 82.3 to 123.5 ind ha $^{-1}$ at SGBB and Point Maud, respectively (note: Lotty's Lagoon was used previously in a reproductive study involving the removal of $\sim 200$ specimens; hence, the naturally occurring density in this area may have been significantly greater).

Broadening the area to include the entire population surveyed (including the outliers positioned at some distance from major aggregations), lower and upper densities of Holothuria whitmaei were estimated at 11.4 to 17.1 ind. ha ${ }^{-1}$, respectively. Hence, although distributed primarily on the outer reef lagoon, the distribution $H$. whitmaei was significantly heterogeneous, ranging from sporadic aggregations containing more than 100 ind. ha ${ }^{-1}$ (Lotty's Lagoon, GBB, SGBB and Point Maud) to relatively sparse patterns of distribution containing 11.4 to 17.1 ind. ha ${ }^{-1}$.

\section{Rates of activity}

Rates of activity increased sharply from very low rates of activity in the morning (1.8 to $\left.3.7 \mathrm{~cm} \mathrm{~h}^{-1}\right)$ to significantly higher rates of activity in the afternoon (13.0 to $31.6 \mathrm{~cm} \mathrm{~h}^{-1}$ ) (Fig. 2, Table 1). Night-time rates of activity (8.2 to $15.1 \mathrm{~cm} \mathrm{~h}^{-1}$ ), although measured with lower resolution (i.e. 12 to $14 \mathrm{~h}$ for $\mathrm{N}$ versus 2 to $4 \mathrm{~h}$ increments for EM, MD and LA), were higher than EM

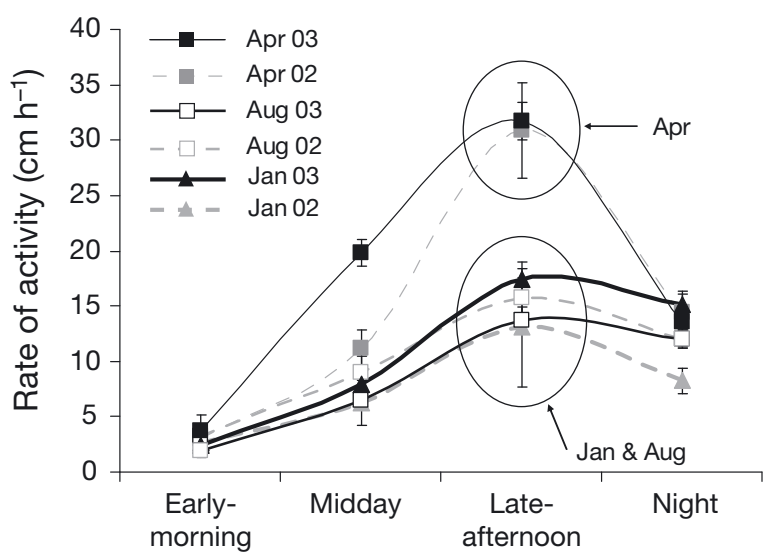

Fig. 2. Holothuria whitmaei. Rates of activity ( $\pm 1 \mathrm{SE}$ ) measured in January, April and August between 2002 and 2003, near Lotty's Lagoon, Ningaloo Reef, Western Australia

Table 1. Holothuria whitmaei. Results of (a) 3-way ANOVA analysing the effect of time of day (T) (repeated measures factor with 4 levels), year (Y) (between subjects random factor with 2 levels) and month (M) (between subjects fixed factor with 3 levels) on rates of activity in $H$. whitmaei, and (b) the 2way ANOVA analysing the effect of $\mathrm{Y}$ and $\mathrm{M}$ on untransformed late afternoon rates of activity. $\mathrm{Y}$ and $\mathrm{M}$ were treated as random and fixed factors, respectively

\begin{tabular}{|lcccc|}
\hline Sources of variation & df & MS & $F$ & $p$ \\
\hline (a) Diurnal and seasonal activity & & & \\
Within subjects effects & & & & \\
$\mathrm{T}$ & 3 & 7295.5 & 181.7 & $<0.01$ \\
$\mathrm{~T} \times \mathrm{Y}$ & 3 & 46.9 & 1.1 & 0.321 \\
$\mathrm{~T} \times \mathrm{M}$ & 6 & 777.9 & 19.3 & $<0.01$ \\
$\mathrm{~T} \times \mathrm{Y} \times \mathrm{M}$ & 6 & 143.3 & 3.5 & 0.002 \\
Error & 435 & 40.1 & & \\
Between subjects factors & & & & \\
$\mathrm{Y}$ & 1 & 194.8 & 1.9 & 0.16 \\
$\mathrm{M}$ & 2 & 2961.5 & 30.3 & $<0.001$ \\
$\mathrm{Y} \times \mathrm{M}$ & 2 & 296.7 & 3.0 & 0.051 \\
Error & 145 & 97.6 & & \\
$(\mathrm{~b})$ Late afternoon activity & & & & \\
Between subjects effects & & & & \\
$\mathrm{Y}$ & 1 & 0.1 & 0.003 & 0.962 \\
$\mathrm{M}$ & 2 & 4113.0 & 78.3 & $<0.05$ \\
$\mathrm{Y} \times \mathrm{M}$ & 2 & 52.5 & 0.41 & 0.662 \\
Error & 146 & 126.8 & & \\
\hline
\end{tabular}


and MD rates of activity, but lower than LA rates of activity (Fig. 2). Rates of activity also differed between months (Table 1), with LA rates of activity being higher in April than in January and August. A 2-way ANOVA testing the effect of month $(\mathrm{M})$ and year $(\mathrm{Y})$ on LA rates of activity, found that LA rates of activity were significantly higher in April than in all other months (Fig. 2), and that this difference was maintained irrespective of year (as indicated by the nonsignificant interaction term $\mathrm{M} \times \mathrm{Y}$ ) (Table 1). Although most pronounced in the LA, differences between April and other months were also apparent in other time increments, most noticeably in the MD time increment (Fig. 2).

\section{Rates of sediment egestion}

On 3 of 6 occasions (January 2002, April 2003, and August 2003), rates of sediment egestion followed a consistent pattern: an EM peak followed by a MD decrease, followed by a LA increase followed again by a $\mathrm{N}$ decline (Fig. 3). Contrasting patterns were apparent in August 2002 and April 2002, when rates of egestion peaked in the MD and LA time intervals, respectively. Temporal variation in sediment egestion was most pronounced in April and August 2003, when rates of sediment egestion were elevated in the EM relative to the MD time increment (Fig. 3). On both occasions, lower rates of sediment egestion around midday were followed by an increase in the rate of sediment egestion in the LA. A similar pattern of diurnal sediment egestion was observed in January 2003 (Fig. 3); though, on this occasion, the magnitude of the diurnal variation was less than that observed in other months of the same year (2003).

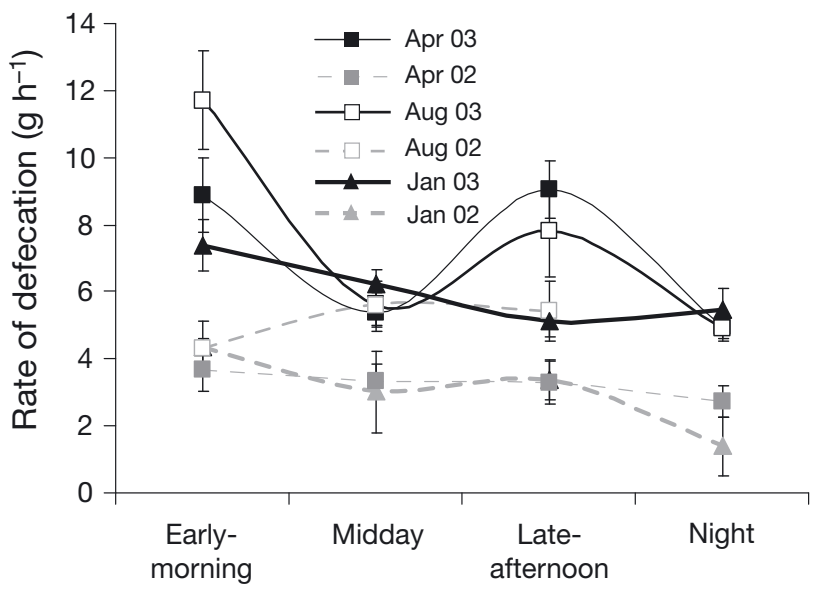

Fig. 3. Holothuria whitmaei. Diurnal rates of sediment egestion $( \pm 1 \mathrm{SE})$ measured in January, April and August over a 2 yr period (2002 and 2003), near Lotty's Lagoon, Ningaloo Reef, Western Australia
Table 2. Holothuria whitmaei. Results of 3-way ANOVA analysing the effect of time of day $(\mathrm{T})$ (repeated measures factor with 4 levels), year (Y) (between subjects factor with 2 levels) and month (M) (between subjects factor with 3 levels) on rates of sediment egestion in $H$. whitmaei

\begin{tabular}{|lcccc|}
\hline Sources of variation & df & MS & $F$ & $p$ \\
\hline Within subjects effects & & & & \\
$\mathrm{T}$ & 3 & 184.9 & 22.5 & $>0.001$ \\
$\mathrm{~T} \times \mathrm{Y}$ & 3 & 9.0 & 1.0 & 0.35 \\
$\mathrm{~T} \times \mathrm{M}$ & 6 & 24.9 & 3.0 & 0.007 \\
$\mathrm{~T} \times \mathrm{Y} \times \mathrm{M}$ & 3 & 35.72 & 4.3 & 0.005 \\
Error & 240 & 8.2 & & \\
Between subjects factors & & & & \\
$\mathrm{Y}$ & 1 & 830.9 & 49.0 & $>0.001$ \\
$\mathrm{M}$ & 2 & 35.1 & 2.0 & 0.013 \\
$\mathrm{Y} \times \mathrm{M}$ & 1 & 18.3 & 1.0 & 0.301 \\
Error & 80 & 16.9 & & \\
& & & & \\
\hline
\end{tabular}

The 3-way ANOVA testing the effect of $\mathrm{Y}$ and $\mathrm{M}$ on rates of sediment egestion revealed that both factors were important in determining the amount of sediment egested. Specifically, factors Y and M (including the between-factors interaction term $\mathrm{Y} \times \mathrm{M}$ ) were highly significant (Table 2). On an annual scale, rates of egestion were higher in 2003 relative to 2002. Seasonal trends, in contrast, were more difficult to establish. The mean values presented in Fig. 3 indicate highly variable results, with little to suggest that rates of sediment egestion increase at certain times of the year.

\section{Relationship between activity and sediment egestion}

The regression between total volume of sediment egested and the total distance travelled (over a $24 \mathrm{~h}$ period) in the months January, April and August was significant (Table 3). Monthly trends, depicted in Fig. 4, were particularly strong in August $\left(\mathrm{r}^{2}=0.57\right)$ relative to April and January $\left(r^{2}=0.32\right.$ and $r^{2}=0.13$, respectively). These data suggest that, while the amount of sediment produced was positively correlated to the distance travelled, the relationship is not absolute given that between 43 and $87 \%$ of the relationship between these factors was explained by other variables.

\section{Sediment retention time}

The period of time between ingestion of indicator sediments and subsequent defecation was difficult to determine accurately. This was because the stained portion of ingested sediment typically emerged before 
Table 3. Holothuria whitmaei. Results of Type II regression analyses of average total distance travelled versus total daily faecal production. Results are presented for the January, April,

August data (pooled across years) and all data combined

\begin{tabular}{|lccccccc|}
\hline Month & $\mathrm{n}$ & $\mathrm{df}$ & $\mathrm{MS}$ & $F$ & $\mathrm{p}$ & $\mathrm{r}^{2}$ \\
\hline January & & & & & & \\
$\quad \begin{array}{l}\text { Regression } \\
\text { Residual }\end{array}$ & 66 & 1 & 606658 & 9.55 & $<0.01$ & 0.13 \\
$\quad$ & & 64 & 63482.1 & & & \\
$\quad \begin{array}{l}\text { Total } \\
\text { April }\end{array}$ & & 65 & & & & \\
$\quad$ Regression & 65 & 1 & 2872150 & 29.9 & $<0.001$ & 0.32 \\
$\quad$ Residual & & 63 & 95910 & & & \\
$\quad$ Total & & 64 & & & & \\
$\begin{array}{l}\text { August } \\
\quad \text { Regression }\end{array}$ & 45 & 1 & 1737145 & 56.4 & $<0.001$ & 0.57 \\
$\quad$ Residual & & 43 & 30802 & & & \\
$\quad$ Total & & 44 & & & & \\
All data & & & & & & \\
$\quad$ Regression & 176 & 1 & 7228597 & 74.6 & $<0.001$ & 0.3 \\
$\quad$ Residual & & 174 & 96898 & & & \\
$\quad$ Total & & 175 & & & & \\
\hline
\end{tabular}

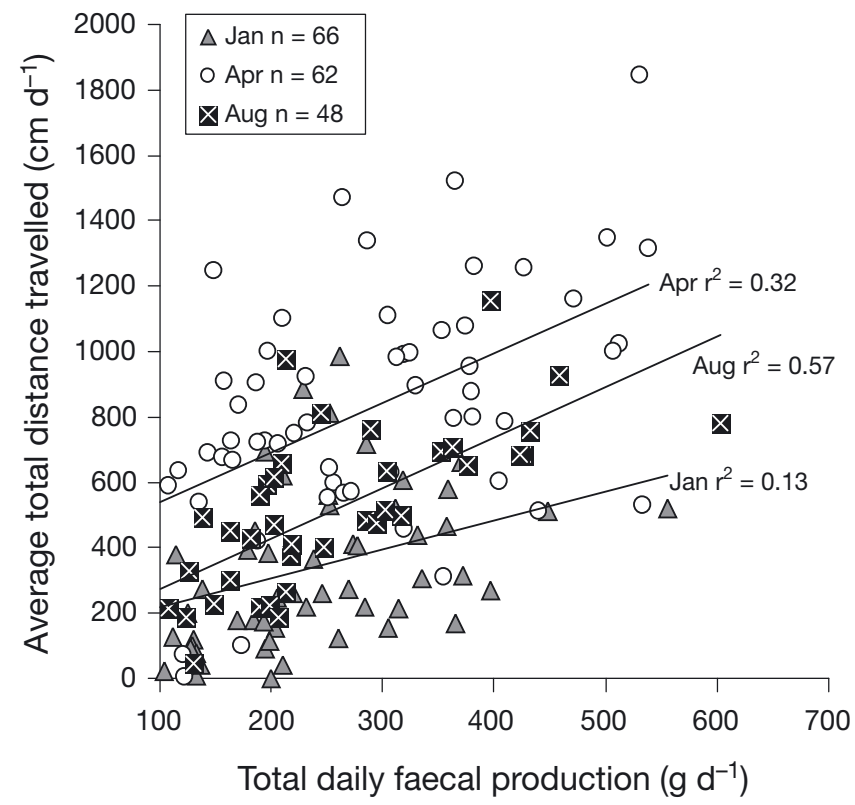

Fig. 4. Holothuria whitmaei. Scatter plots and regression coefficient of determination values $\left(\mathrm{r}^{2}\right)$ for average total distance travelled versus average total daily sediment egestion

the beginning of the EM monitoring period. However, on 4 of 20 occasions when indicator sediments were offered, a coloured 'plug' of indicator sediment was observed in the faeces during the MD monitoring period, about 16 to $17 \mathrm{~h}$ following initial ingestion. Most individuals, however, required less time $(<14 \mathrm{~h})$ to egest the indicator sediment.

\section{Bioturbation}

Rates of sediment bioturbation differed markedly between years and months (Table 4). Data presented in Table 4 consist of mean estimates of bioturbation (as rates) and an estimate of the actual surface area processed at population densities encountered near Coral Bay. Greater volumes of marine sediments $\left(\mathrm{g}\right.$ ind. $\left.{ }^{-1} \mathrm{~d}^{-1}\right)$ were processed on average in 2003 relative to 2002 . Similarly, large variation was apparent between months, with the greatest average ( $g$ ind. ${ }^{-1} \mathrm{~d}^{-1} \pm 1 \mathrm{SD}$ ) volumes processed in August $2003(170 \pm 64)$ followed in descending order by April 2003 (144 \pm 59$)$, August 2002 (136 \pm 60), January $2003(121 \pm 38)$, January 2002 $(82 \pm 44)$ and April $2002(80 \pm 46)$.

When averaged across each of the study periods (January, April and August), the daily bioturbation contribution of Holothuria whitmaei measured as the rate of sediment ingested was $122 \pm 52 \mathrm{~g} \mathrm{ind}^{-1} \mathrm{~d}^{-1}$ (Table 4), equivalent to $44 \pm 19 \mathrm{~kg}$ of sediment per individual per annum. At the population level, the total volume of sediment bioturbated per annum was calculated conservatively to range between $762 \pm 322 \mathrm{~kg}$

Table 4. Holothuria whitmaei. Calculated rates of sediment ingestion and the area of sediment bioturbated to a depth of $5 \mathrm{~mm}$ (the approximate depth of sediment ingested by deposit feeding holothurians). The area of sediment ingested to a depth of $5 \mathrm{~mm}$ is also provided as a percentage (\%) of the total available sediment surface area. $\mathrm{n}=18$ for January and April 2002; otherwise $n=30$

\begin{tabular}{|c|c|c|c|c|}
\hline $\begin{array}{l}\text { Study } \\
\text { period }\end{array}$ & $\begin{array}{c}\text { Daily } \\
\text { amount }\end{array}$ & $\mathrm{SD}$ & $\begin{array}{l}\text { Annual } \\
\text { amount }\end{array}$ & $\mathrm{SD}$ \\
\hline \multicolumn{5}{|c|}{ Mean sediment turnover per individual (kg) } \\
\hline Jan 2002 & 0.082 & 0.044 & 29.89 & 16.03 \\
\hline Apr 2002 & 0.080 & 0.046 & 29.17 & 16.91 \\
\hline Aug 2002 & 0.136 & 0.060 & 49.49 & 22.08 \\
\hline Jan 2003 & 0.121 & 0.038 & 44.13 & 13.84 \\
\hline Apr 2003 & 0.144 & 0.059 & 52.66 & 21.46 \\
\hline Aug 2003 & 0.170 & 0.064 & 62.11 & 23.39 \\
\hline Mean & 0.122 & 0.052 & 44.57 & 18.95 \\
\hline \multicolumn{5}{|c|}{ Mean sediment area ingested to $5 \mathrm{~mm}\left(\mathrm{~m}^{2}\right.$ ind. $\left.{ }^{-1}\right)$} \\
\hline Jan 2002 & 0.013 & 0.007 & 4.73 & 2.54 \\
\hline Apr 2002 & 0.013 & 0.007 & 4.62 & 2.68 \\
\hline Aug 2002 & 0.021 & 0.010 & 7.84 & 3.50 \\
\hline Jan 2003 & 0.019 & 0.006 & 6.99 & 2.19 \\
\hline Apr 2003 & 0.023 & 0.009 & 8.34 & 3.40 \\
\hline Aug 2003 & 0.027 & 0.010 & 9.84 & 3.70 \\
\hline Mean & 0.019 & 0.008 & 7.06 & 3.00 \\
\hline \multicolumn{5}{|c|}{ Mean $\%$ total surface area bioturbated per hectare $\left(\% \mathrm{ha}^{-1}\right)$} \\
\hline Jan 2002 & 0.0003 & 0.0001 & 0.095 & 0.051 \\
\hline April 2002 & 0.0003 & 0.0001 & 0.092 & 0.054 \\
\hline Aug 2002 & 0.0004 & 0.0002 & 0.157 & 0.070 \\
\hline Jan 2003 & 0.0004 & 0.0001 & 0.140 & 0.044 \\
\hline Apr 2003 & 0.0005 & 0.0002 & 0.167 & 0.068 \\
\hline Aug 2003 & 0.0005 & 0.0002 & 0.197 & 0.074 \\
\hline Mean & 0.0004 & 0.0002 & 0.141 & 0.060 \\
\hline
\end{tabular}


Table 5. Holothuria whitmaei. Mean daily $\left(\mathrm{m} \mathrm{d}^{-1} \pm \mathrm{SD}\right.$ ) and annual (total $\mathrm{m} \pm \mathrm{SD}$ ) distance travelled by individuals and area of sediment surface area contacted $\left(\mathrm{m}^{2} \pm \mathrm{SD}\right)$ by the trivium (foot) of individuals at 2 defined densities and at different times during 2002 and 2003. $\mathrm{n}=18$ for January and April 2002; otherwise $\mathrm{n}=30$

\begin{tabular}{|c|c|c|c|c|c|c|}
\hline \multirow[t]{2}{*}{ Study period } & \multicolumn{2}{|c|}{$\begin{array}{l}\text { Mean distance travelled } \\
\text { per individual }(\mathrm{n}=18-30)\end{array}$} & \multicolumn{2}{|c|}{$\begin{array}{l}\text { Surface area contacted } \\
\text { at } 17.1 \text { ind. }^{-1} a^{-1}\end{array}$} & \multicolumn{2}{|c|}{$\begin{array}{l}\text { Surface area contacted } \\
\text { at } \geq 100 \text { ind. }^{-1} a^{-1}\end{array}$} \\
\hline & $\begin{array}{l}\text { Daily } \\
\left(\mathrm{m} \mathrm{d}^{-1}\right)\end{array}$ & $\begin{array}{c}\text { Annual } \\
\text { (total m) }\end{array}$ & $\begin{array}{l}\text { Daily } \\
\left(\mathrm{m}^{2}\right)\end{array}$ & $\underset{\left(\mathrm{m}^{2}\right)}{\text { Annual }}$ & $\begin{array}{l}\text { Daily } \\
\left(\mathrm{m}^{2}\right)\end{array}$ & $\begin{array}{c}\text { Annual } \\
\left(\mathrm{m}^{2}\right)\end{array}$ \\
\hline Jan 2002 & $1.59 \pm 1.89$ & $580.7 \pm 690.2$ & $3.24 \pm 3.8$ & $1183.8 \pm 1407.0$ & $18.96 \pm 22.5$ & $6922.9 \pm 8228.2$ \\
\hline Apr 2002 & $2.81 \pm 1.72$ & $1027.5 \pm 628.9$ & $5.73 \pm 3.5$ & $2094.4 \pm 1282.0$ & $33.55 \pm 20.5$ & $12248.3 \pm 7497.2$ \\
\hline Aug 2002 & $2.40 \pm 1.62$ & $893.5 \pm 593.9$ & $4.90 \pm 3.3$ & $1821.2 \pm 1210.6$ & $29.18 \pm 19.3$ & $10650.7 \pm 7079.6$ \\
\hline Jan 2003 & $2.12 \pm 1.27$ & $774.3 \pm 465.1$ & $4.32 \pm 2.5$ & $1578.4 \pm 948.1$ & $25.28 \pm 15.1$ & $9230.6 \pm 5544.6$ \\
\hline Apr 2003 & $4.37 \pm 1.39$ & $1596.0 \pm 508.9$ & $8.91 \pm 2.8$ & $3253.3 \pm 1037.4$ & $52.12 \pm 16.6$ & $19025.1 \pm 6066.7$ \\
\hline Aug 2003 & $2.23 \pm 1.33$ & $817.3 \pm 487.9$ & $4.56 \pm 2.7$ & $1665.9 \pm 994.5$ & $26.69 \pm 15.9$ & $9742.3 \pm 5816.1$ \\
\hline Mean & $2.59 \pm 1.54$ & $948.2 \pm 562.5$ & $5.29 \pm 3.14$ & $1932.8 \pm 1146.6$ & $30.98 \pm 18.3$ & $11303.3 \pm 6705$ \\
\hline
\end{tabular}

based on average densities (17.1 ind. ha $\left.{ }^{-1}\right)$, and $4457 \pm$ $1896 \mathrm{~kg}$ based on higher densities ( $\geq 100$ ind. ha ${ }^{-1}$ ), such as those found in aggregations.

The total average daily volume of sediment bioturbated by individual Holothuria whitmaei $(122 \pm 52 \mathrm{~g}$ ind. ${ }^{-1} \mathrm{~d}^{-1}$ ) is equivalent to the ingestion of approximately $96 \mathrm{~cm}^{3}$, or $193 \mathrm{~cm}^{2}\left(0.019 \mathrm{~m}^{2}\right)$ of coral reef sediment to a depth of $5 \mathrm{~mm}$ (Table 4). Mean ingestion of sediment area per annum over the range of densities measured at Coral Bay, i.e. 17.1 to $\geq 100$ ind. ha ${ }^{-1}$, ranged between $120 \pm 51 \mathrm{~m}^{2}(0.012 \mathrm{ha})$ and $705 \pm$ $300 \mathrm{~m}^{2}$ (0.070 ha), respectively. Hence, the total volume of sediment processed, while taking into account the range of densities encountered, is 2.0 to $14 \%$ of the total available sediment in a 1 ha area per annum.

The total distance travelled by Holothuria whitmaei over a $24 \mathrm{~h}$ period differed markedly between months, with distances being greater in April relative to January and August. The data presented in Table 5 consists of distance and surface area values for January, April and August (2002 and 2003 studies inclusive), and average values derived by pooling the monthly data. The mean distance travelled varied significantly, ranging between 159 to $437 \mathrm{~cm} \mathrm{~d}^{-1}$ in January 2002 and April 2003, respectively. These values are conservatively equivalent to total distances of $580 \mathrm{~m} \mathrm{yr}^{-1}$ and $1596 \mathrm{~m} \mathrm{yr}^{-1}$, respectively (Table 5). Multiplication of the total distance travelled by the diameter of the trivium yielded an estimate of the sediment area in contact with the base of the sea cucumber (Table 5). A single H. whitmaei specimen contacts $\sim 0.30 \mathrm{~m}^{2}$ of sediment per day, or $113 \mathrm{~m}^{2}$ of sediment per annum. At high densities, such as within aggregations (>100 ind. ha ${ }^{-1}$ ), the total area of sediment contacted was estimated conservatively as approximately 2 times the total available coral reef sediment per hectare per annum (based on the assumption that sediment accounts for $\sim 50 \%$ of the coral reef habitat area as described by Rasheed et al. 2002).

\section{DISCUSSION}

\section{Density, distribution and aggregation}

The present study used a number of methods to measure the density and distribution of sea cucumbers consisting of stratified manta tows, blanket manta tows and GIS to estimate densities within aggregations. At Coral Bay, Ningaloo, individuals of Holothuria whitmaei were distributed upon the outer reef lagoon, thus comparing broadly with the findings of previous studies (Conand 1985, 1990, 1993, Massin \& Doumen 1986, Uthicke \& Benzie 2000a). However, the distribution (and therefore density) of individuals was not uniform. Rather, density estimates were influenced heavily by the presence of species aggregates; specifically, individuals were preferentially located in habitats exposed to prevailing water movement, which at Coral Bay flows predominantly northward along the inner reef crest (Hearn et al. 1986, Sanderson 1996).

Densities of 19.3 to 27.1 ind. ha ${ }^{-1}$ reported here based on stratified manta tows compare well with estimates from reefs protected from fishing on the GBR (Uthicke \& Benzie 2000a, Byrne et al. 2004). However, these values are many times lower than the densities obtained in aggregations at sites GBB, SGBB and Point Maud (upper estimates of 78.5 to 123.5 ind. ha ${ }^{-1}$ ). Densities of Holothuria whitmaei greater than 100 ind. ha ${ }^{-1}$ are not unprecedented, but are seldom reported for adult specimens. Densities of 100 ind. ha ${ }^{-1}$ and 275 ind. $\mathrm{ha}^{-1}$ were reported on reefs of Papua New Guinea (Lokani 1990) and New Caledonia (Conand 1989), respectively, and more recently densities of ca. 120 ind. $\mathrm{ha}^{-1}$ were measured on Raine Island, GBR (Byrne et al. 2004); though, in the latter examples, specimens were distinctly smaller and located within sea grass habitats. At Coral Bay, densities within aggregations were 7.2 times greater than those obtained over the full range of distribution (based on an upper estimate of 17.1 ind. 
$\mathrm{ha}^{-1}$ following blanket manta tows) and 4.5 to 6.3 times greater than those obtained using stratified manta tows (19.3 to 27.1 ind. ha ${ }^{-1}$ ).

Design of appropriate census methods requires careful consideration of the biology of the target species, including knowledge of species boundaries, diurnal and/or cryptic behaviour and the tendency to form aggregations (Andrew \& Mapstone 1987, Graham \& Battaglene 2004, Shiell \& Knott 2008). We have demonstrated that even careful placement of transects (based on a priori knowledge of habitat preferences) may considerably underestimate or overestimate population densities. This may be exacerbated particularly when individuals of a species have a tendency to aggregate, as we have shown here (see also Andrew \& Mapstone 1987). Andrew \& Mapstone (1987) suggest that the smallest unit area included in a density survey should, where feasible, be larger than the average spacing among aggregations. At Coral Bay, the distance between aggregation centroids varied considerably $(0.9 \mathrm{~km}$ between $\mathrm{GBB}$ and $\mathrm{SGBB}$ and $3.1 \mathrm{~km}$ between GBB and Point Maud), suggesting that information compiled from a much larger area than is included here would be required to determine an appropriate sampling unit for this species. Nevertheless, estimates of between 11.4 to 17.1 ind. ha ${ }^{-1}$, calculated by including only habitats occupied by Holothuria whitmaei (considered a reasonable estimate of the species' boundary), may represent minimum natural population densities for this species on Ningaloo Reef, Western Australia.

Aggregation among holothurians is a phenomenon typically associated with reproduction. Mercier et al. (2000) noted increasing prevalence of pairs, trios or larger groups of Holothuria scabra just before the full moon (a cue known to precede spawning in some holothurians, Babcock et al. 1986) and aggregation among deep-sea holothurians has been attributed to synchronised reproductive events and food availability (Gutt \& Piepenburg 1991). Tyler et al. (1992) proposed that spawning among pairs or trios of deep-sea holothurians is driven by conspecific rather than seasonal cues, and that simultaneous gonad development and spawning increases the probability of fertilisation (see also Levitan \& Young 1995). We contend that the aggregations observed at Ningaloo may represent an adaptation for improving reproductive success, which may otherwise be impeded where individuals are separated by large distances (see also the Allee effect in Levitan \& Petersen 1995). Research is warranted to determine the significance of these aggregations, which could reasonably be expected to achieve higher rates of larval fertilisation and contribute disproportionately large numbers of seed to surrounding reefs.

\section{Temporal behaviour: rates of activity and sediment egestion}

When measured along the length of the faecal trail, the total distance travelled yielded values at least twice those obtained from measuring the straight line distance alone. Hence, comparison of the data presented here with distances travelled along a straight line (Parker 1921, Yamanouti 1939, Hammond 1982, Uthicke 2001a), both by linear displacement over time (Graham \& Battaglene 2004) and by calculation based on polar co-ordinates (Da Silva et al. 1986), is possible only with appropriate adjustment. Arbitrarily halving the overall minimum and maximum daily rates of activity obtained in the present study yields values of 3.3 to $9.1 \mathrm{~cm} \mathrm{~h}^{-1}$, values slightly lower than those reported in other large aspidochirotes (Parker 1921, Yamanouti 1939, Hammond 1982, Da Silva et al. 1986, Uthicke 2001a). However, higher values are derived by halving the late afternoon rates of activity: 6.5 and $15.8 \mathrm{~cm} \mathrm{~h}^{-1}$ for rates in January 2002 and April 2003, respectively.

Diurnal rates of activity were found to increase between EM (07:30 to $10: 30 \mathrm{~h})$ and LA (15:30 to $18: 30 \mathrm{~h}$ ). Increasing activity between EM to LA is common in large aspidochirotes, having been described in Holothuria mexicana, Isostichopus badionotus, Stichopus chloronotus and Actinopyga mauritiana (Hammond 1982, Uthicke 1994, Graham \& Battaglene 2004). EM periods of reduced activity have also been linked with periods of corresponding cryptic behaviour, whereby individual animals tended to remain hidden beneath coral (Shiell \& Knott 2008).

Superimposed on this diurnal pattern was a seasonal pattern, with significantly increased daily activity in April compared with January and August. This trend, detected in 2002 and 2003, coincided with the annual peak in water temperature and the annual gonadal index (Shiell \& Uthicke 2006). The significant temporal pattern of increasing activity in April, relative to January and August is, to our knowledge, the first to be described in tropical aspidochirotes. Knowledge of factors influencing seasonal activity among holothurians, without considering the presumed concurrent process of feeding, is scarce and typically reported in terms of migratory behaviour. Movement or migration of aspidochirote sea cucumbers is reported in response to water currents (Gutt \& Piepenburg 1991), sensitivity to water temperature (Mercier et al. 2000) and, in coral reef species, upon reaching sexual maturity (Reichenbach 1999). Environmental influences on activity, when considered in the context of feeding, are more common. However, efforts to find correlations between rates of sediment egestion and environmental variables in the present study were met with limited success. 
Rates of sediment egestion were observed to peak in the early morning period, 15 to $16 \mathrm{~h}$ following the late afternoon peak in activity, on 3 of 6 sampling occasions. Increased rates of sediment egestion following a similar time lag (between peak rates of activity and defecation) are reported in Holothuria mexicana and Isostichopus badionotus (Hammond 1982). In the present study, the length of time between the initial ingestion of sediment and final defecation was $\sim 14$ to $17 \mathrm{~h}$, approximately the length of time between the late afternoon period of heightened activity and the morning period of increased defecation. Higher rates of defecation $\sim 17 \mathrm{~h}$ after the late afternoon peak in activity may represent a conservative estimate of the time lag between periods of enhanced feeding, nighttime digestive processes and subsequent defecation in $H$. whitmaei.

In the present study, the annual contribution of Holothuria whitmaei to bioturbation was found to be minimal in comparison to that of other tropical aspidochirotes. For example, under typical densities, $H$. atra and Stichopus chloronotus, two of the most abundant tropical holothurians of the Indo-Pacific, process at least $100 \%$ of the upper $5 \mathrm{~mm}$ of coral reef sediments per annum (Uthicke 1999). In marked contrast, H. whitmaei, even at very high densities (>100 ind. $\mathrm{ha}^{-1}$ ) was predicted to process only $14.1 \%$ of the available sediment, on average. This estimate reduces further to approximately 2 to $3 \%$ when extrapolated based on densities obtained (1) over the full range of distribution (17.1 ind. ha ${ }^{-1}$ ) and (2) by the average of stratified manta tows (23 ind. ha ${ }^{-1}$ ). Nonetheless, the large area of sediment contacted by $H$. whitmaei (approximately twice the available sediment area per hectare per annum) may have significant benefits for coral reef ecosystems. Uthicke $(2001 \mathrm{a}, \mathrm{b})$, for example, showed that the slow movement of holothurians serves to (1) maximise the period of contact between the animals and the sediment and (2) subject small patches of sediment to repeated doses of inorganic nutrients. Hence, despite the relatively small contribution of $H$. whitmaei to bioturbation, through its activity, $H$. whitmaei may play a significant role in facilitating the recycling of nutrients at the sediment-water interface, thereby contributing to the overall health of habitats occupied by this species.

Acknowledgements. We acknowledge the funding of an ARC linkage grant to B.K. and additional funding and infrastructure provided by B. Elliot, Oceanwest Fisheries, R. Hall, Bawinanga Aboriginal Corporation, and G. Bebb and M. Denise (Surpac Business Development). Additional financial support was kindly supplied by the School of Animal Biology, The University of Western Australia. Original versions of the manuscript benefited from comments and suggestions by Professor C. Conand and Dr. K. Friedman, and later versions from 3 anonymous referees. The authors are grateful for the assistance provided by Dr. B. Radford and indebted to H. Maitland, Dr. S.-M. Wolkenhauer, N. Malo and the people of Coral Bay for invaluable logistical support. All data were collected pursuant to Western Australian Government Department of Conservation and Land Management regulations (permit nos. NE002561, SF003678 and SF003678).

\section{LITERATURE CITED}

Aller RC, Yingst JY (1985) Effect of marine deposit feeders Heteromastus filiformis (Polychaeta), Macoma balthica (Bivalvia) and Tellina texana (Bivalvia) on averaged sedimentary solute transport, reaction rates, and microbial distributions. J Mar Res 43:615-645

Amon RMW, Herndl GJ (1991) Deposit feeding and sediment: 1. Interrelationship between Holothuria tubulosa (Holothurioidea, Echinodermata) and the sediment microbial community. PSZN I: Mar Ecol 12:163-174

Andrew NL, Mapstone BD (1987) Sampling and the description of spatial patterns in marine ecology. In: Barnes $\mathrm{H}$, Barnes $M$ (eds) Oceanography and marine biology: an annual review. The Dunstaffnage Marine Research Laboratory Oban, Argyll, Scotland. Aberdeen University Press, Aberdeen, p 39-90

Babcock RC, Bull GD, Harrison PL, Heyward AJ, Oliver JK, Wallace CC, Willis BL (1986) Synchronous spawnings of 105 scleractinian coral species on the Great Barrier Reef. Mar Biol 90:379-394

Bakus GJ (1973) The biology and ecology of tropical holothurians. In: Jones OA, Endean R (eds) Biology and geology of coral reefs. VII. Biology 1. Academic Press, New York, NY, p 325-367

Birkeland C (1988) The influence of echinoderms on coral-reef communities. In: Jangoux M, Lawrence JM (eds) Echinoderm studies 3. AA Balkema, Rotterdam, p 1-79

Byrne M, Smoothey A, Hogget A, Uthicke S (2004) Population biology of shallow water holothuroids and ophiuroids from Rain Island and Moulter Cay, Northern Great Barrier Reef. In: Heizeller T, Nebelsick JH (eds) Proceedings of the 11th International Echinoderm Conference, Munich. Taylor \& Francis, London, p 165-169

Chen J (2004) Present status and prospects of sea cucumber industry in China. In: Lovatelli A (comp/ed), Conand C, Purcell S, Uthicke S, Hamel JF, Mercier A (eds) Advances in sea cucumber aquaculture and management. FAO Fish Tech Pap No. 463, Rome, p 25-38

Cliff AD, Ord JK (1981) Spatial processes models and applications. Pion Limited, London

Conand C (1981) Sexual cycle of three commercially important holothurian species (Echinodermata) from the lagoon of New Caledonia. Bull Mar Sci 31:523-543

Conand C (1985) Are the aspidochirote holothurians of the New Caledonian lagoon good indicators of the reefal features? In: Gabrié C (ed) Proc 5th Int Coral Reef Congr, Tahiti 2:291-296

Conand C (1989) Les holothuries aspidochirotes du lagon de Nouvelle-Calédonie: Biologie, écologie et exploitation. Etudes et thèses ORSTOM, Paris

Conand C (1990) The fishery resources of Pacific island countries. Part 2. Holothurians. FAO Fish Tech Pap No. 272.2, Rome

Conand C (1993) Reproductive biology of the holothurians from the major communities of the New Caledonian Lagoon. Mar Biol 116:439-450 
Conand C (2004) Present status of world sea cucumber resources and utilization: an international overview. In: Lovatelli A (comp/ed), Conand C, Purcell S, Uthicke S, Hamel JF, Mercier A (eds) Advances in sea cucumber aquaculture and management. FAO Fish Tech Pap No. 463, Rome, p 13-24

> Da Silva J, Cameron JL, Fankboner PV (1986) Movement and orientation patterns in the commercial sea cucumber Parastichopus californicus (Stimpson) (Holothuroidea: Aspidochirotida). Mar Behav Physiol 12:133-147

Ferdouse F (2004) World markets and trade flows of sea cucumber/bêche-de-mer. In: Lovatelli A (comp/ed), Conand C, Purcell S, Uthicke S, Hamel JF, Mercier A (eds) Advances in sea cucumber aquaculture and management. FAO Fish Tech Pap No. 463, Rome, p 101-117

Fowler J, Cohen L, Jarvis P (1998) Practical statistics for field biology, 2nd edn. John Wiley \& Sons, Brisbane

Graham J, Battaglene SC (2004) Periodic movement and sheltering behaviour of Actinopyga mauritiana (Holothurioidea: Aspidochirotida) in Solomon Islands. SPC Bêchede-mer Info Bull 19:23-31

Gutt J, Piepenburg D (1991) Dense aggregations of three deep-sea holothurians in the southern Weddell Sea, Antarctica. Mar Ecol Prog Ser 68:277-285

Hammond LS (1981) An analysis of grain size modification in biogenic carbonate sediments by deposit feeding holothurians and echinoids (Echinodermata). Limnol Oceanogr 26:898-906

Hammond LS (1982) Patterns of feeding and activity in deposit-feeding holothurians and echinoids (Echinodermata) from a shallow back-reef lagoon, Discovery Bay, Jamaica. Bull Mar Sci 32:549-571

Hammond LS, Birtles RA, Reichelt RE (1985) Holothuroid assemblages on coral reefs across the central section of the Great Barrier Reef. In: Gabrié C (ed) Proc 5th Int Coral Reef Congr, Tahiti 2:285-290

Hearn CJ, Hatcher BG, Masini RJ, Simpson CJ (1986) Oceanographic processes on the Ningaloo Coral Reef, Western Australia. Center for Water Research, Environmental Fluid Dynamics Report ED-86-171. The University of Western Australia, Nedlands, WA

Hooge PN, Eichenlaub B (1997) Animal movement extension to ArcView. Version 1.1. US Geological Survey, Alaska Science Center, Biological Science Office, Anchorage, AK

Kinch J, Purcell S, Uthicke S, Friedman K (2008) Population status, fisheries and trade of sea cucumbers in the Western Central Pacific. In: Toral-Granda V, Lovatelli A, Vasconcellos M (eds) Sea cucumbers: a global review of fisheries and trade. FAO Fish Tech Pap No. 516, Rome

Klinger TS, Johnson CR, Jell J (1994) Sediment utilisation, feeding niche breadth, and feeding niche overlap in Aspidochirotida (Echinodermata: Holothuroidea) at Heron Island, Great Barrier Reef. In: David B, Guille A, Feral JP, Roux M (eds) Echinoderms (Dijon), Proc 8th Int Echinoderm Conf. AA Balkema, Rotterdam, p 523-528

Lawrence AJ, Ahmed M, Hanafy M, Gabr H, Ibrahim A, GabAlla AAFA (2004) Status of the sea cucumber fishery in the Red Sea-the Egyptian experience. In: Lovatelli A (comp/ed), Purcell S, Uthicke S, Hamel JF, Mercier A (eds) Advances in sea cucumber aquaculture and management. FAO Fish Tech Pap No. 463, Rome, p 79-90

> Levitan DR, Petersen C (1995) Sperm limitation in the sea. Trends Ecol Evol 10:228-231

> Levitan DR, Young C (1995) Reproductive success in large populations: empirical measures and theoretical predictions of fertilisation in the sea biscuit Clypeasterrosaceus. J Exp Mar Biol Ecol 190:221-241
Lokani P (1990) Bêche-de-mer research and development in Papua New Guinea. SPC Bêche-de-mer Info Bull 2:1-18

Long B, Skewes T, Dennis D, Poiner I and others (1996) Distribution and abundance of bêche-de-mer on Torres Strait Reefs. Final report to the Queensland Fisheries Management Authority, Brisbane

Martinez PC, Richmond RH (1998) Effects of diet on growth and larval development of the sea cucumber Holothuria nobilis in Guam. In: Moori R, Telford M (eds) Echinoderms: San Francisco. Proc 9th Int Echinoderm Conf, San Francisco. AA Balkema, Rotterdam, p 480 (Abstract)

Massin C (1982a) Food and feeding mechanisms: Holothuroidea. In: Jangoux M, Lawrence JM (eds) Echinoderm nutrition. AA Balkema, Rotterdam, p 43-55

Massin C (1982b) Effects of feeding on the environment: Holothuroidea. In: Jangoux M, Lawrence JM (eds) Echinoderm nutrition. AA Balkema, Rotterdam, p 493-497

Massin C, Doumen C (1986) Distribution and feeding of epibenthic holothuroids on the reef flat of Laing Island (Papua New Guinea). Mar Ecol Prog Ser 31:185-195

Mercier A, Battaglene SC, Hamel JF (2000) Periodic movement, recruitment and size related distribution of the sea cucumber Holothuria scabra in the Solomon Islands. Mar Biol 440:81-100

Moran PAP (1950) Notes on continuous stochastic phenomena. Biometrika 40:19-32

Parker GH (1921) The locomotion of the holothurian Stichopus panamensis Clark. J Exp Zool 33:205-208

Preston GL (1993) Bêche-de-mer. In: Wright A, Hill L (eds) Nearshore marine resources of Ha'pai, Tonga. SPC Institute of Pacific Studies, Suva, p 371-408

Rasheed M, Badran MI, Richter C, Huettel M (2002). Effect of reef framework and bottom sediment on nutrient enrichment in a coral reef of the Gulf of Aqabar, Red Sea. Mar Ecol Prog Ser 239:277-285

Rees M, Colquhoun J, Smith L, Heyward A (2003) Stocks of trochus, bêche-de-mer and clams at Ashmore Reef, Cartier Reef and Mermaid Reef, Northwestern Australia. Report produced for Environment Australia. Australian Institute of Marine Science, Townsville

Reichenbach N (1999) Ecology and fishery biology of Holothuria fuscogilva (Echinodermata: Holothuroidea) in the Maldives, Indian Ocean. Bull Mar Sci 64:103-113

Sanderson PG (1996) Cuspate forelands of the west coast of Western Australia. PhD thesis, The University of Western Australia, Nedlands, WA

Shiell GR (2006) Effect of invasive tagging on the activity of Holothuria whitmaei [Echinodermata: Holothuroidea]: a suitable mark-recapture method for short-term field studies of holothurian behaviour. Mar Freshw Behav Physiol 39:153-162

Shiell GR, Knott B (2008) Diurnal observations of sheltering behaviour in the coral reef sea cucumber Holothuria whitmaei. Fish Res 91:112-117

> Shiell GR, Uthicke S (2006) Reproduction of the commercial sea cucumber Holothuria whitmaei [Aspidochirotoda: Holothuroidea] in the Pacific and Indian Ocean regions of Australia. Mar Biol 148:973-986

Toral-Granda V, Lovatelli A, Vasconcellos M (eds) (2008) Sea cucumbers: a global review of fisheries and trade. FAO Fish Tech Pap No. 516, Rome

Tyler PA, Young CM, Billett DSM, Giles LA (1992) Pairing behaviour, reproduction and diet in the deep-sea holothurian genus Paroriza (Holothuroidea: Synallactidae). J Mar Biol Assoc UK 72:447-462

Uthicke S (1994) Distribution patterns and growth of two reef flat holothurians, Holothuria atra and Stichopus chlorono- 
tus. In: David B, Guille A, Féral JP, Roux M (eds) Echinoderms through time. Proc 8th Int Echinoderm Conf, 6-10 September 1993, Dijon, p 569-575

Uthicke S (1999) Sediment bioturbation and impact of feeding activity of Holothuria (Halodeima) atra and Stichopus chloronotus, two sediment feeding holothurians, at Lizard Island, Great Barrier Reef. Bull Mar Sci 64:129-141

Uthicke S (2001a) Nutrient regeneration by abundant coral reef holothurians. J Exp Mar Biol Ecol 265:153-170

Uthicke S (2001b) Interactions between sediment-feeders and microalgae on coral reefs: grazing losses versus production enhancement. Mar Ecol Prog Ser 210:125-138

Uthicke S, Benzie JAH (2000a) Effect of bêche-de-mer fishing on densities and size structure of Holothuria nobilis [Echinodermata: Holothuroidea] populations on the Great Barrier Reef. Coral Reefs 19:271-276

Uthicke S, Benzie JAH (2000b) Allozyme electrophoresis indicates high gene flow between populations of Holothuria (Microthele) nobilis (Holothuroidea: Aspidochirotida) on the Great Barrier Reef. Mar Biol 137: 819-825

Uthicke S, Benzie JAH (2002) A genetic fingerprint recapture technique for measuring growth in 'unmarkable' invertebrates: negative growth in commercially fished holothurians (Holothuria nobilis). Mar Ecol Prog Ser 241: 221-226

Uthicke S, Benzie JAH (2003) Gene flow and population history in high dispersal marine invertebrates: mitochondrial

Editorial responsibility: Matthias Seaman,

Oldendorf/Luhe, Germany
DNA analysis of Holothuria nobilis (Echinodermata: Holothuroidea) populations from the Indo-Pacific. Mol Ecol 12:2635-2648

- Uthicke S, Karez R (1999) Sediment patch selectivity in tropical sea cucumbers (Holothuroidea: Aspidochirotida) analysed with multiple choice experiments. J Exp Mar Biol Ecol 236:69-87

Uthicke S, Klumpp DW (1998) Microphytobenthos community production in sediments of a near shore coral reef: seasonal variation and response to ammonium recycled by holothurians. Mar Ecol Prog Ser 169:1-11

Uthicke S, O'Hara TD, Byrne M (2004) Species composition and molecular phylogeny of the Indo-Pacific teatfish (Echinodermata: Holothuroidea) bêche-de-mer fishery. Mar Freshw Res 55:837-848

Wiedmeyer WL (1992) Feeding behaviour of two tropical holothurians Holothuria (Metriatyla) scabra (Jäger, 1833) and $H$. (Halodeima) atra (Jäger, 1833), from Okinawa, Japan. In: Richmond RH (ed) Proc 7th Int Coral Reef Symp, Guam, USA, Vol 2, p 854-860

Wolkenhauer SM, Uthicke U, Burridge C, Skewes T, Pitcher R (2010) The ecological role of Holothuria scabra (Echinodermata: Holothuroidea) within subtropical seagrass beds. J Mar Biol Assoc UK 90:215-233

Yamanouti T (1939) Ecological and physiological studies on holothurians in the coral reef of Palao Islands. Palao Trop Biol Stn Stud 25:603-636

Submitted: November 10, 2009; Accepted: May 31, 2010 Proofs received from author(s): September 6, 2010 